Research

\title{
Fishermen's perceptions and experiences toward the impact of climate change and anthropogenic activities on freshwater fish biodiversity in Côte d'Ivoire
}

\author{
Amien Isaac Amoutchi ${ }^{1} \cdot$ Thomas Mehner $^{2} \cdot$ Ogechi Nnabuchi Ugbor $^{1,3} \cdot$ Alpha Kargbo $^{1,4} \cdot$ Kouamelan Essetchi Paul $^{5}$
}

Received: 4 October 2021 / Accepted: 19 November 2021

Published online: 08 December 2021

(C) The Author(s) $2021 \quad$ OPEN

\begin{abstract}
Africa's freshwater ecosystems are impacted by many threats due to climate change and several anthropogenic activities. In Côte d'Ivoire, the economy relies mostly on agriculture, which covers around $64 \%$ of the land surface. The study aimed to investigate Côte d'Ivoire fishermen's perception of climate change, its drivers and other anthropogenic activities impacting freshwater fish biodiversity. The fish species locally threatened in the Ivorian freshwater ecosystems were also investigated. Face to face interviews and a structured questionnaire were used. The data obtained were analysed using descriptive statistics such as frequency, percentage, means, and standard deviation, minimum and maximum. The multinomial logit regression was also applied to test factors that influence fishermen's awareness and perception of climate change and their perception of change in fish abundance. The results show that around $72.7 \%$ of fishermen were aware of climate change. Decreases of precipitation (87.9\%) and increases of temperature (76.1\%) were observed by fishermen. Also, a significant decrease in fish quantity was observed by respondents. Climate change and anthropogenic activities such as gold mining, water withdrawal, use of small-mesh fishing nets, overfishing, industrial waste pollution, pesticides use for agricultural purposes along watersheds, obnoxious fishing practices and population growth, were highlighted as the main reasons for this decline. Species such as Lates niloticus, Heterotis niloticus, Parachanna obscura, Malapterurus electricus, Sarotherodon galilaeus, Tilapia zillii, Polpyterus endlicheri and Labeo coubie were listed by fishermen as locally threatened within Ivorian freshwater ecosystems. Actions and policies are needed to be taken by local authorities to ensure the sustainability of fisheries resources. The information obtained from this study constitutes a prerequisite for developing and implementing studies or policies aimed at mitigating and combating the negative effect of climate change and anthropogenic activities on the Ivorian freshwater ecosystem.
\end{abstract}

Keywords Anthropogenic activities · Climate change · Freshwater fish biodiversity · Fishermen · Côte d'Ivoire

$\triangle$ Amien Isaac Amoutchi, amoutchiamienisaac@gmail.com | ${ }^{1}$ West African Science Service Centre on Climate Change and Adapted Land Use (WASCAL) Graduate Research Program on Climate Change and Biodiversity, Université Felix Houphouet-Boigny, Abidjan, Côte d'Ivoire. ${ }^{2}$ Leibniz-Institute of Freshwater Ecology and Inland Fisheries, Berlin, Germany. ${ }^{3}$ Department of Fisheries and Aquatic Resources Management, Michael Okpara University of Agriculture Umudike, Umuahia, Nigeria. ${ }^{4}$ Department of Physical and Natural Sciences, University of The Gambia, Brikama Campus, P. O Box 3530, Serrekunda, The Gambia. ${ }^{5}$ Laboratoire d'Hydrobiologie, UFR Biosciences, Université Felix Houphouët Boigny, 22, BP 582, Abidjan 22, Côte d'Ivoire.

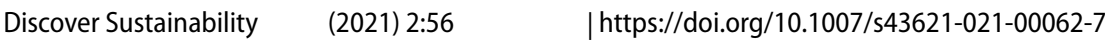




\section{Introduction}

The United Nations Framework Convention on Climate Change (UNFCCC) defined climate change as "a change of climate which is attributed directly or indirectly to human activity that alters the composition of the global atmosphere and which is in addition to natural climate variability observed over comparable periods" [1]. Most aquatic organisms are very sensitive to any variation in their environment. Combined effects of climatic factors, overfishing, increased human population growth, water pollution and alien invasive species, are amongst the stressors that contribute to the degradation of natural water resources, consequently threatening aquatic systems [2]. Recently, it was noted that aquatic biodiversity is threatened and subject to severe declines in many countries [2]. Among aquatic ecosystems, freshwater ecosystems are most sensitive to environmental disturbances [3]. Freshwater organisms have the highest proportion of known species globally categorized as extinct or threatened in the International Union for Conservation of Nature (IUCN) Red List [4, 5]. A report of the United Nations Educational, Scientific and Cultural Organization (UNESCO) indicated a faster decline of freshwater biodiversity than of terrestrial and marine biodiversity over the last three decades [6]. The decline is expected to accelerate even further with warmer temperatures, reduced precipitation and increased water withdrawal for agriculture and other human use $[7,8]$.

Africa harbours a diversified fish fauna resulting from a long history of complex climatic and geological events that resulted in geographic isolation followed by speciation for some populations, or extinction for others [9]. African ichthyofauna shows numerous exceptional features compared to other continents. However, Africa's ichthyofauna shares affinities with those of both South America and Asia [9]. Thus, Africa's freshwater fish biodiversity is reported to comprise more than 3000 species, more or close to that of Asia (more than 3600 species known) and South America (more than 4200 species known) [10]. Climate change and other anthropogenic perturbations such as dam construction, water extraction and overexploitation are some of the stressors impacting Africa's freshwater biodiversity [9, 11]. Also, habitat modification, caused by various land uses and associated sedimentation is reported as one of the most widespread threats to freshwater fishes in Africa [12]. Sediments cover submerged surfaces, increase turbidity, and reduce suitable habitats for breeding and feeding of many fish populations [9]. Water pollution represents a problem for freshwater fish in several parts of Africa. Pesticides and fertilizers' impact on African's freshwater ecosystems have been well-documented $[13,14,11]$.

In Côte d'Ivoire, the economy relies mostly on agriculture, which covers around 64\% of the land surface [15]. From 1960 to 2018 , the country's rate of urbanization soared from $17.7 \%$ to over $50 \%$ [16]. The high rate of urbanisation, combined with agriculture expansion, are susceptible to impact aquatic ecosystems, especially those of the freshwaters, in this country. Pollution of aquatic ecosystems from the discharge of untreated domestic, industrial, and agricultural wastes have been reported in the country [17-19]. Regarding the climate of this country, from the 1980s to $2000 \mathrm{~s}$ temperature increased on average by $0.5^{\circ} \mathrm{C}$, and from 2001 to 2010 a temperature rise of $0.8^{\circ} \mathrm{C}$ was recorded [20]. The decades 1950s and 1960s were recorded to be comparatively wetter than those from 1970 to $1990 \mathrm{~s}$ which were drier. Moreover, according to the prediction of The Intergovernmental Panel on Climate Change in 2014 under RCP4.5 scenario, temperature will rise of $3^{\circ} \mathrm{C}$ by 2100 , over most of the country from north to south, and the daily precipitation will drop by $8 \%$ relative to its current amount during the season from April to July over the next hundred years [20]. Thus, climate change and human activities may constitute a real threat to freshwater fish biodiversity in this country. Consequently, there is an urgency to provide a scientific assessment of the impact of climate change and human activities on Côte d'Ivoire freshwater biodiversity, which will guide management strategies.

Over time, Indigenous peoples throughout the world have preserved distinctive understandings, rooted in cultural experience, that guide relationships among human and non-human beings in specific ecosystems. These understandings and relationships constitute a system broadly identified as indigenous knowledge [21]. Indigenous knowledge is part of the heritage of humankind. It is the library of knowledge that people have of the environments where they live [22]. Fishermen are people depending directly on the services provided by the aquatic ecosystem for their livelihoods. Therefore, they are most affected by any environmental disturbance in this ecosystem, and also the key group well aware of the nature of the disturbance. Their perception of climate change (the existence, the impact, and causes) and knowledge of anthropogenic activities impacting freshwater fish biodiversity, being part of their indigenous knowledge, are essential for making and implementing decisions and policies related to the mitigation of these threats, and the management of freshwater fish biodiversity. Furthermore, fishermen's knowledge and perception represent the baseline information for motivating and directing any research projects regarding this issue. 
In this view, this study aimed to investigate Ivorian fishermen's knowledge and perception towards climate change, its drivers, and human activities impacts on freshwater fish biodiversity and the species locally vulnerable.

\section{Materials and methods}

\subsection{Study area}

The study was carried out in Cote d'Ivoire, West Africa. The country is divided by latitude into three principal climatic zones, with a fourth zone being the particular climate of the mountain zone. Our study was carried out in three climatic zones within Cote d'Ivoire: Guinean in the south, Sudano-Guinean in the middle and Sudanian in the northern (Fig. 1). Guinean zone, also known as Attiean zone, is characterized by a sub-equatorial climate with two rainy seasons and two dry seasons. Its annual precipitation is estimated to be more than $1500 \mathrm{~mm}$ [20]. Fishermen of Bia River, Ayame lake and Faye Lake within Krindjabo, Bianou, Alliekro and Ayame localities were randomly selected in this climate zone. The Sudano-guinean or Baoulean zone is characterized by an equatorial transition climate between the Guinean and the sudanian climates. This climate zone also has two rainy seasons and two dry seasons, with the annual precipitation comprising between 1200 and $1500 \mathrm{~mm}$ per year. Within this climate zone, fishermen of Kan lake, Buyo lake and Nzo river, from Koubi, Dibobly and Guiglo localities were selected for the study. Within the Sudanian zone, the fishermen of Bagoue river from Samorosso village were selected. The Sudanian zone is characterized by one rainy season and one dry season. The annual precipitation varies between 900 and $1200 \mathrm{~mm}$.

\subsection{Sampling of fishermen}

The study was conducted as part of a project titled "Predicting the impact of climate change and anthropogenic activities on the distribution and genetic diversity of Parachanna species in Côte d'Ivoire" funded by the West African service centre of Climate Change and Adapted Land-use scholarship programme, for three years and half (started in September 2019). Thus, a preliminary investigation was done in the three selected climatic zones with 90 fishermen, to identify the proportion of them fishing or trading on Parachanna fish species among their global target species. The fishermen selected were those who were familiar with Parachanna species and who had already been involved in fishing or trading on Parachanna species. These fishermen were also involved in fishing or trading other common fish species found at the sampling sites. The survey was conducted among fishermen in different types of freshwater ecosystems, including

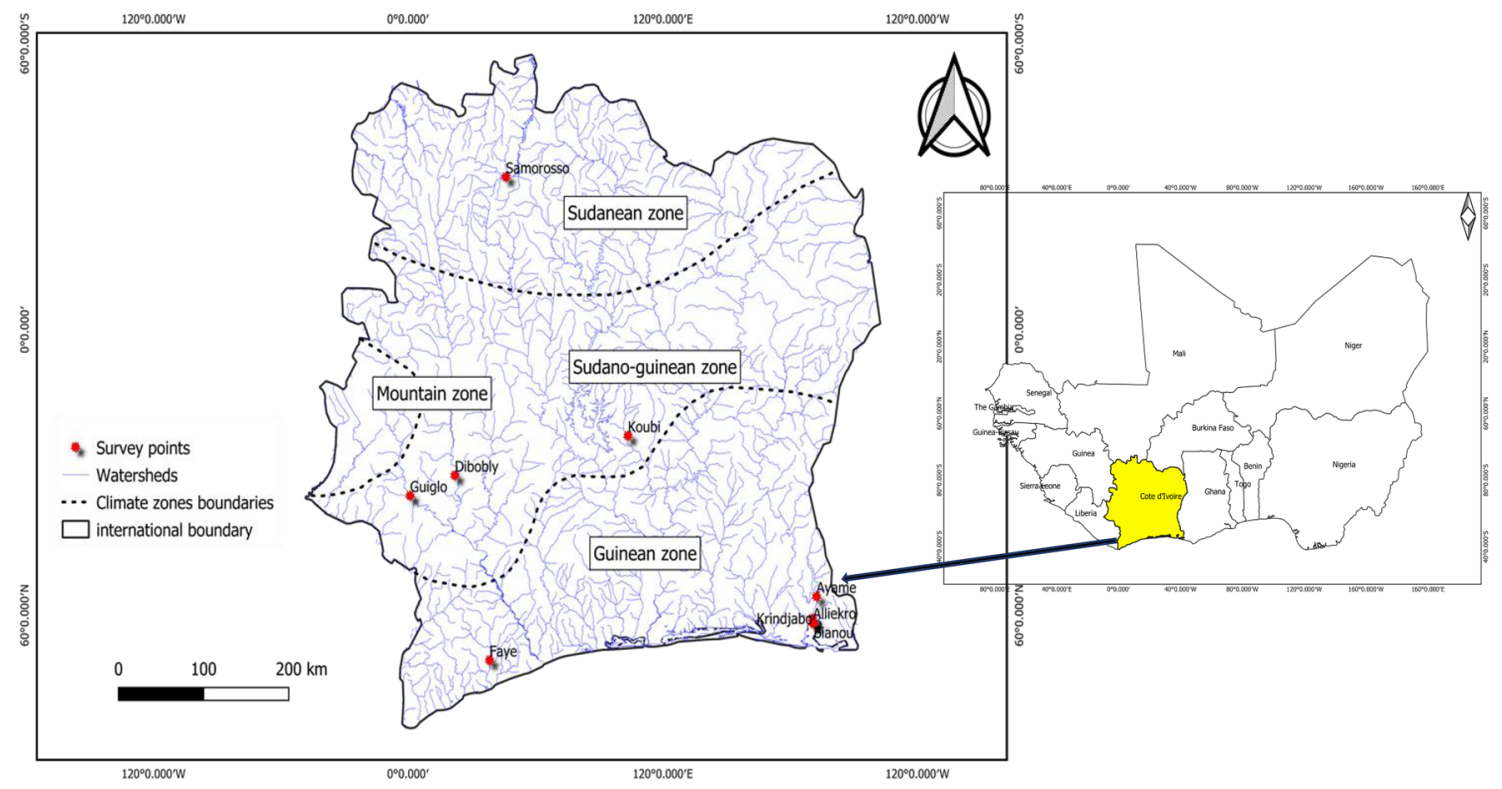

Fig. 1 The study area map, showing the borders of Côte d'Ivoire, its position in West Africa, the main climate zones and the locations where surveys were conducted 
lakes, rivers and streams. The investigation resulted in the proportion of $60 \%$ of fishermen fishing on Parachanna among the global interviewed fishermen. This proportion was used in [23] formula with a $95 \%$ confidence level to calculate the necessary sample size:

$$
\mathrm{N}=\frac{U_{1-\alpha / 2}^{2} \mathrm{p}(1-\mathrm{p})}{\mathrm{d}^{2}}
$$

$\mathrm{N}=$ the total number of fishermen to be surveyed; $\mathrm{U}^{2}{ }_{1-\mathrm{a} / 2}$ represents the value of the normal random variable for a probability value of $1-\alpha / 2=0.975 ; U_{1-\alpha / 2}^{2}=1.96 ; p$ represents the estimated proportion of fishermen fishing on Parachanna fish species among their target species, obtained from the preliminary investigation $(p=0.60)$; $d$ is the margin of error of a parameter estimated from the sample fixed at 0.05 . From the formula, the sample size of 369 fishermen was the minimum needed, but to be more accurate, 381 fishermen were interviewed in this study.

\subsection{Data collection}

Face to face interviews were conducted using a structured questionnaire from October 2020 to February 2021. Fishermen were randomly selected on each sampling site. Fish landing sites within each sampling site were used as collection sites. The questionnaire was divided into three sections (Appendix 1). The first section was structured to assess the respondent's general demographic background (e.g., age, sex, household size, education level, occupation, monthly income, etc.) and the second section was on the fishermen's knowledge of climate change (e.g., awareness, causes and drivers, perceived change in variables, etc.). The last section was linked to respondents' perception of the impact of climate change and human activities on freshwater fish biodiversity (e.g., change in fish quantity, how climate change drew change in fish biodiversity, major human activities threatening freshwater fish biodiversity, locally threatened fish species).

\subsection{Data analysis}

Descriptive statistics (frequency, percentage, means and standard deviation, minimum and maximum) were calculated to analyse fishermen's demographic information, their perception related to climate change and its impact on freshwater fish biodiversity and their perception of human impact on fish biodiversity. The multinomial logit regression model (MLN) was applied to analyse factors that influence fishermen's awareness of climate change, their perception of climate change, and their perception of change in fish abundance. This model has been widely used in many studies to test factors that influence individual knowledge of climate change, climate adaptation and climate change risk perception [24, 25]. The multinomial logit regression is used to predict the probability of category membership of a dependent variable based on several independent (predictor) variables. The MLN model is a simple extension of the binary logit regression that allows for more than two categories of the dependent or independent variables. In this model, the independent variables can either be nominal or ordinal [26]. MLN uses maximum likelihood estimation to evaluate the probability of categorical membership in a dependent variable based on multiple predictor variables. In this study, we considered sociodemographic variables (e.g., age, gender, education level, household size, ethnic group) of fishermen as the predictors and perception variables (e.g., awareness of climate change, perceived change in climate or fish quantity) as dependent variables. The MLN results reflect the expected change in the probability that fishermen perceive climate change or fish quantity change or be aware of climate change with respect to a one-unit change in a predictor variable, keeping all the other predictors constant. Alpha (a) lesser than 0.05 was considered statistically significant. SPSS version 2.2 software was used for the descriptive statistics, while the multinomial logit regression was implemented in R 3.6.3 software.

\section{Result}

\subsection{Socio-demographic background of respondents}

A total of 381 questionnaires were successfully completed. $81.9 \%$ of respondents were males and $18.1 \%$ were females. Most (63\%) of the respondents were between 30 to 49 years old, followed by those belonging to the ages ranging from 50 to $59(17.8 \%)$, and 20 to 29 (13.6\%). Only 5.5\% of the respondents were 60 years and above. Among interviewed people, $84.5 \%$ were married, $15.2 \%$ single and $0.3 \%$ divorced. The household sizes of respondents were 
principally between 1 to 10 persons (85.5\%), followed by 11 to 15 persons (12.1\%), 16 to 20 persons (1.0\%), then 26 persons and above (1.3\%). The largest proportion of the respondents (43.3\%) were illiterates (no formal education). Then, $28.6 \%, 23.1 \%$ and $3.4 \%$ had primary, high school and university education, respectively (Table1).

\subsection{Livelihood strategies of the fishermen}

Whereas $80 \%$ of the respondents were engaged in fishing as their main occupation, $14.2 \%$ were only engaged in fish trade. The remaining percentage was shared among farming, teaching and shopkeeping. Regarding the secondary occupation, respondents were mostly involved in farming (59.1\%), followed by fishing (3.9\%), fish trading (2.6\%), livestock farming (1.6\%), and others (11.8\%). Around $21 \%$ of respondents were not engaged in any secondary activities.

Concerning fishermen" monthly incomes, the arithmetic mean monthly income was about $130 \mathrm{EUR}$, with a minimum of 15 EUR and a maximum of 763 EUR. However, it varied among the climate zones. Thus, Guinean climate zone fishermen had the highest mean monthly incomes of about 145 EUR. Comparatively, Sudano-Guinean climate zone fishermen recorded the middle monthly mean income (126 EUR), more than those of Sudanian climate zone with the lowest one (93 EURO). The complete results of the interviewees' livelihood are presented in Tables 2 and 3.

Table 1 Overview of the socio-demographic background of 381 respondents to a questionnaire on the perception of climate change and changes in fish biodiversity and their potential drivers in Côte d'Ivoire

\begin{tabular}{|c|c|c|c|c|c|}
\hline Respondents & Frequency & Percentage & Respondents & Frequency & Percentage \\
\hline Gender & & & Ethnic group & & \\
\hline Female & 69 & 18.1 & Abron & 1 & 0.3 \\
\hline Male & 312 & 81.9 & Agni & 75 & 19.7 \\
\hline Total & 381 & 100.0 & Apollo & 4 & 1.0 \\
\hline Age & & & Bambara (Mali) & 17 & 4.5 \\
\hline [20-29] & 52 & 13.6 & Baoulé & 65 & 17.1 \\
\hline [30-39] & 119 & 31.2 & Bozo (Mali) & 63 & 16.5 \\
\hline [40-49] & 121 & 31.8 & Dioula & 8 & 2.1 \\
\hline [50-59] & 68 & 17.8 & Guéré & 57 & 15.0 \\
\hline$\geq 60$ & 21 & 5.5 & Keke (mali) & 3 & 0.8 \\
\hline Total & 381 & 100.0 & Koroboro (Mali) & 7 & 1.8 \\
\hline Marital status & & & Samogo & 57 & 15.0 \\
\hline Married & 322 & 84.5 & Senoufo & 14 & 3.7 \\
\hline Single & 58 & 15.2 & Songhaï (Mali) & 9 & 2.4 \\
\hline Divorce & 1 & 0.3 & Tagbana & 1 & 0.3 \\
\hline Total & 381 & 100.0 & Total & 381 & 100.0 \\
\hline Household size & & & Watershed & & \\
\hline$[1-5]$ & 154 & 40.4 & Bia river & 58 & 15.2 \\
\hline$[6-10]$ & 172 & 45.1 & Lake Ayame & 58 & 15.2 \\
\hline [11-15] & 46 & 12.1 & Lake Buyo & 48 & 12.6 \\
\hline [16-20] & 4 & 1.0 & Lake faye & 55 & 14.4 \\
\hline$\geq 26$ & 5 & 1.3 & Lake Kan & 64 & 16.8 \\
\hline Total & 381 & 100.0 & River Bagoue & 54 & 14.2 \\
\hline Education level & & & River Nzo & 44 & 11.5 \\
\hline No formal education & 165 & 43.3 & Total & 381 & 100.0 \\
\hline Primary & 109 & 28.6 & Climate zone & & \\
\hline Junior high school & 63 & 16.5 & Guinean climate & 171 & 44.9 \\
\hline Senior high school & 25 & 6.6 & Sudano-guinean climate & 156 & 40.9 \\
\hline University & 13 & 3.4 & Sudanian climate & 54 & 14.2 \\
\hline Koranic school & 6 & 1.6 & Total & 381 & 100.0 \\
\hline Total & 381 & 100.0 & & & \\
\hline
\end{tabular}


Table 2 Livelihood strategies of 381 respondents to a questionnaire on the perception of climate change and change in fish biodiversity and their potential drivers in Côte d'Ivoire

\begin{tabular}{llll}
\hline Respondents & Percentage & Respondents & Percentage \\
\hline Main occupation & & Secondary occupation & \\
Fishing & 80 & Fishing & 3.9 \\
Fish Trading & 14.2 & Farming & 59.1 \\
Farming & 3.4 & Fish Trading & 2.6 \\
Teaching & 0.3 & Livestock farming & 1.6 \\
Shopkeeping & 2.1 & None & 21 \\
Total & 100.0 & Other & 11.8 \\
& & Total & 100 \\
\hline
\end{tabular}

Table 3 Monthly income of 381 respondents to a questionnaire on the perception of climate changes and changes in fish biodiversity and their potential drivers, from three Ivorian climatic zones

\begin{tabular}{lclllc}
\hline Climate zone & Mean & $\begin{array}{l}\text { Standard } \\
\text { Deviation }\end{array}$ & Minimum & Maximum & \% of Total N \\
\hline Monthly income (EUR) & & & & & \\
$\quad$ Guinean climate & 145 & 7.34 & 15 & 610 & $44.9 \%$ \\
Sudano-guinean climate & 126 & 8.24 & 17 & 763 & $40.9 \%$ \\
$\quad$ Soudanean climate & 93 & 7.63 & 15 & 183 & $14.2 \%$ \\
Total & 130 & 4.91 & 15 & 763 & $100.0 \%$ \\
\hline
\end{tabular}

Fig. 2 Circular diagram summarizing in percentage the perception of 381 Ivorian's fishermen of causes and drivers of climate change

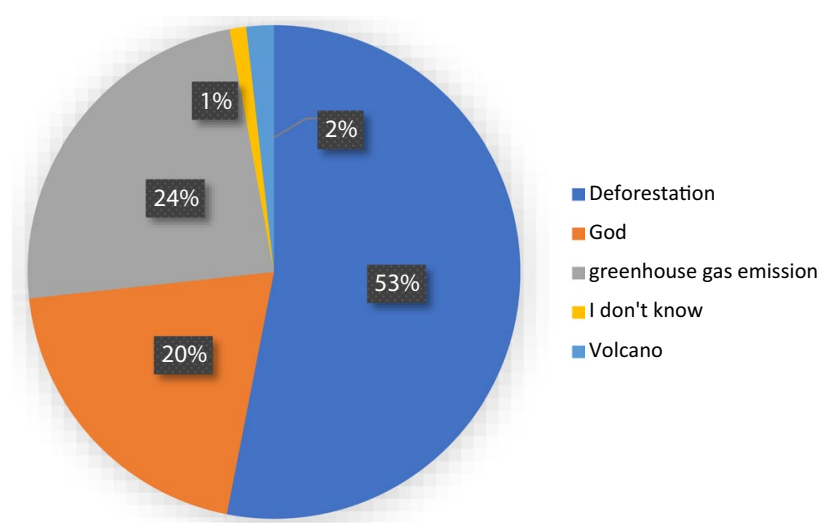

\subsection{Fishermen's perception of climate change, its drivers, its impact on Ivorian freshwater fish abundance}

About $72.7 \%$ of fishermen were aware of climate change, whereas $27.3 \%$ were not. Of the total percentage of the respondents who were aware of climate change, $53 \%$ and $24 \%$ believed that the drivers of climate change are deforestation and greenhouse gas emissions, respectively, whereas $20 \%$ of the respondents attribute the cause of climate change to the will of God, and $2 \%$ believe that natural processes such as volcanic eruptions are the main cause of climate change (Fig. 2). A decrease in precipitation (87.9\%) and an increase in temperature (76.1\%) were observed by respondents. Additionally, interviewees testified to have observed delay in the onset of the rainy season and its length shortening (Fig. 3). Concerning the occurrence of floods, 55.6, 3.7, and $40.7 \%$ of the respondents observed an increase, decrease and no change respectively (Table 4).

Most of the fishermen reported significant decreases in fish abundance (81.6\%), while 10.0, 3.4, and 5\% observed little, moderate and no decrease, respectively. Concerning the impact of climate change on fish abundance, the respondents stated that change in temperature has mainly led to a decrease in fish abundance (65.9\%), while $3.4 \%$ of the respondents argued that change in temperature has led to an increase in fish abundance, $22.8 \%$ observed no effect and $7.9 \%$ did not know. As far as the effect of change in precipitation on the fish abundance is concerned, $71.1 \%$ of the respondents specified that it has led to a decrease, $8.1 \%$ to an increase, and $5 \%$ did not know. For the remaining $15.7 \%$, change in precipitation has not affected fish abundance. 

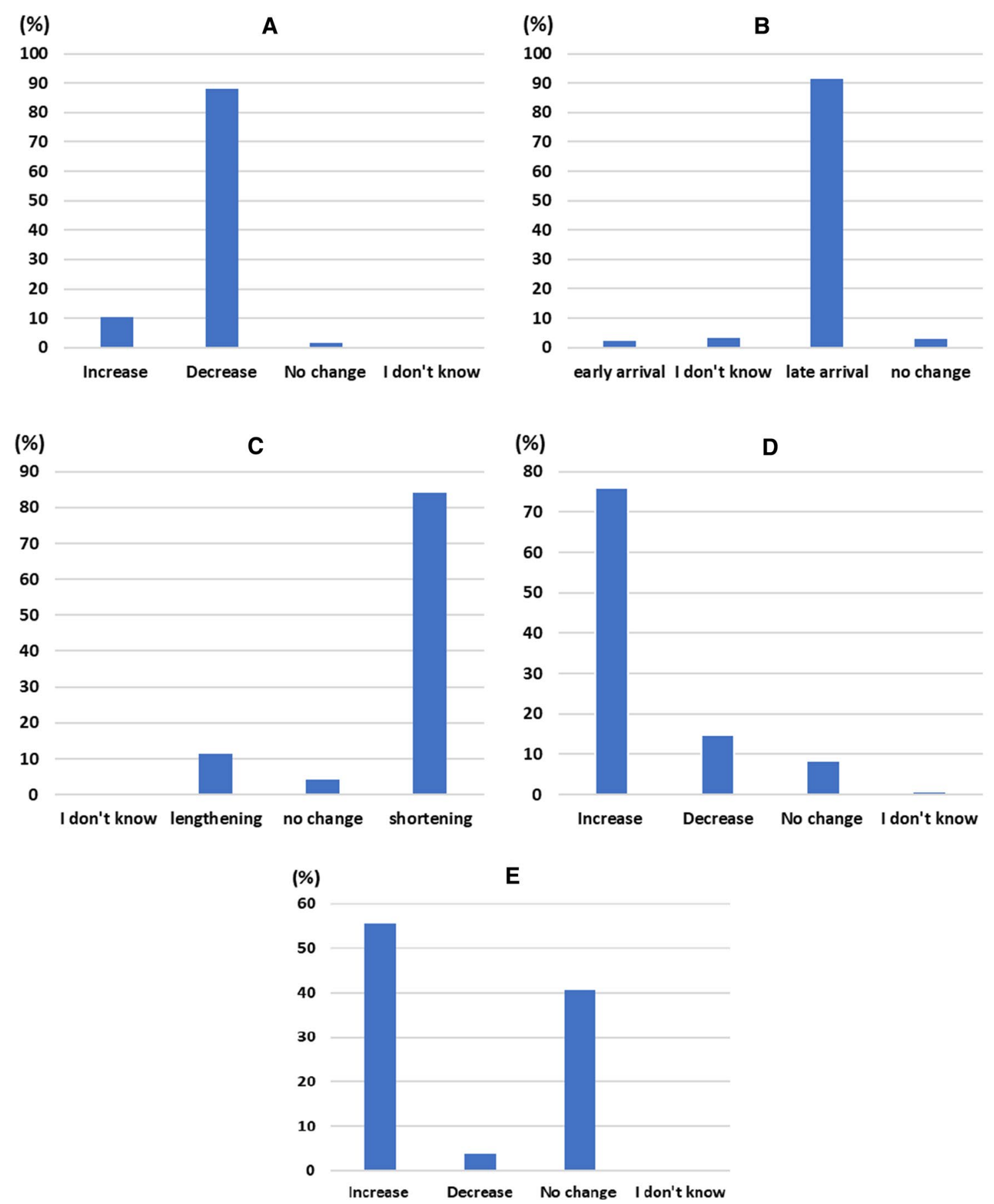

Fig. 3381 Fishermen's responses concerning their perception of $\mathbf{A}$ change in rainfall, $\mathbf{B}$ change in rainy season timing and $\mathbf{C}$ length, D change of temperature, and $\mathbf{E}$ change in flooding occurrence in Côte d'Ivoire. $\mathbf{y}$ axis is the respondent percentage, $\mathbf{x}$ axis represents the categories of responses in the considered change climate attribute

\subsection{Fishermen's perception of the Anthropogenic stressors on freshwater fish}

Table 4 shows the perception of interviewees on the impact of human activities on the Ivorian freshwater fish. Gold mining, water withdrawal for human needs, use of small-mesh fishing nets, overfishing, industrial waste discharge, pesticides use for agricultural purposes along watersheds, obnoxious fishing practices and increase in human 
Table 4 Anthropogenic activities threatening Ivorian freshwater fish biodiversity according to fishermen of the watersheds sampled

\begin{tabular}{|c|c|c|}
\hline Watershed & Stressor & Percentage (\%) \\
\hline \multirow[t]{5}{*}{ Bia river $(\mathrm{N}=58)$} & Obnoxious fishing practices & 44.8 \\
\hline & Gold mining & 22.4 \\
\hline & Overfishing & 31.0 \\
\hline & Use of small-mesh fishing nets & 1.7 \\
\hline & Total & 100 \\
\hline \multirow[t]{5}{*}{ Lake Ayame $(\mathrm{N}=58)$} & Gold mining & 44.8 \\
\hline & Overfishing & 41.4 \\
\hline & water withdrawal for human needs & 6.9 \\
\hline & Obnoxious fishing practices & 6.9 \\
\hline & Total & 100 \\
\hline \multirow[t]{7}{*}{ Lake Faye $(\mathrm{N}=55)$} & Use of small-mesh fishing nets & 16.4 \\
\hline & Water withdrawal for human needs & 14.6 \\
\hline & Industrial waste discharge & 12.7 \\
\hline & Overfishing & 10.9 \\
\hline & Hydrological dams & 1.8 \\
\hline & None & 43.6 \\
\hline & Total & 100 \\
\hline \multirow[t]{6}{*}{ Lake Buyo $(\mathrm{N}=48)$} & Pesticides use for agricultural purposes along watersheds & 66.7 \\
\hline & Overfishing & 10.4 \\
\hline & Water withdrawal for human needs & 4.2 \\
\hline & Obnoxious fishing practices & 4.2 \\
\hline & I don't know & 14.6 \\
\hline & Total & 100 \\
\hline \multirow[t]{3}{*}{ Nzo river $(\mathrm{N}=44)$} & Pesticides use for agricultural purposes along watersheds & 97.7 \\
\hline & I don't know & 2.3 \\
\hline & Total & 100 \\
\hline \multirow[t]{4}{*}{ Lake Kan (N=64) } & Overfishing & 40.6 \\
\hline & Pesticides use for agricultural purposes along watersheds & 18.8 \\
\hline & None & 40.6 \\
\hline & Total & 100 \\
\hline \multirow[t]{6}{*}{ River Bagoue $(\mathrm{N}=54)$} & Overfishing & 42.6 \\
\hline & Obnoxious fishing practices & 20.4 \\
\hline & Increase in population growth & 3.7 \\
\hline & None & 20.4 \\
\hline & I don't know & 12.9 \\
\hline & Total & 100 \\
\hline
\end{tabular}

population, were identified by Ivorian fishermen as the major anthropogenic perturbations affecting Côte d'Ivoire freshwater fish biodiversity. Specifically, fishermen of Bia River argued that the river is mainly impacted by obnoxious fishing practices (44.8\%), overfishing (31.0\%) and gold mining (22.4\%). The use of small-mesh fishing nets (1.7\%) was also identified as a stressor for the fish biodiversity of this river. Fishermen in the artificial lake Ayame, resulting from the construction of the hydroelectric dam on Bia River, identified in decreased order, gold mining (44.8\%), overfishing (41.4\%), water withdrawal and obnoxious fishing practices as stressors of the fish biodiversity in this lake. Use of small-mesh fishing nets, water withdrawal and industrial waste discharge were recognised as factors threatening fish diversity of lake Faye. Pesticides used for agricultural purposes along watersheds were implicated as the main human activity that threatens Buyo lake and Nzo River fish communities. Regarding Kan Lake located within the Sudano-Guinean climate zone and Bagoue river located in the Sudanian climate zone, overfishing was perceived to be the principal factor of fish biodiversity decline. 


\subsection{Fish species locally under threats according to the fishermen}

This section summarizes the fish species within Ivorian freshwaters for which fishermen perceived drastic population declines, such that they are considered to be very scarce over the past years. Tilapia zillii and Malapterurus electricus were the principal fish species listed by Bia River fishermen, while those of Ayame lake mainly identified Heterotis niloticus and Parachanna obscura. Labeo cubii, Parachanna obscura and Tilapia zillii species were mostly reported threatened within buyo Lake. Meanwhile, Heterotis niloticus was the only species reported threatened by Faye Lake fishermen. About $89.1 \%$ of the interviewees from the area surrounding Kan Lake identified Tilapia zillii as under threat in this lake. About River Bagoue and lake Nzo, no species was identified by the fishermen as being threatened in these water bodies (Table 5).

\subsection{Factors influencing fishermen's awareness of climate change and perception of change climate}

Tables 6 and 7 present the results of the multinomial logit regression models concerning the variables that influence respondents' awareness and perception of climate change.

Variables such as climatic zone, household size and education level were significantly associated with respondents' awareness of climate change. Positive relationships between respondents' education level and awareness of climate change were found, meaning that respondents' awareness increased with high education level. The same positive relationship was found with respondents' household size, which increased fishermen's awareness of climate change. However, a negative relationship was obtained between fishermen's awareness of climate change and the climate zone. Thus, respondent awareness of climate change decreased when going from the Guinean forest zone to the Sudanean savanna zone.

Concerning fishermen's perception of climate change, age, household size, gender, and education level were strongly influencing fishermen's perception of change in rainfall. A decrease in rainfall was mainly observed by young adults, males, and low education level fishermen. Perceived change in temperature was significantly influenced by fishermen's fishing watersheds and ethnic groups. Perception of temperature decreases decreased when going from Bia River, Lake Ayame, Lake Buyo, Lake Faye, Lake Kan, Bagoue River to Nzo River fishermen. Perceived change in flooding was significantly determined by watersheds, ethnic group, main occupation and household size.

\subsection{Factors determining fishermen's perception of change in fish quantity}

Change in fish abundance was significantly associated with respondents' age, education level, ethnic group and climate zone. Perceived decrease in fish abundance (low, moderate, and significant) increases with an increase in respondents' ages. Positive relationships between fishermen's education level and their perception of significant decrease in fish abundance were observed (Table 8). Fishermen's perception of significant decrease in fish abundance increased when going from the Guinean climate zone to the Sudanean zone.

\section{Discussion}

Climate change has become the focus of scientists, politicians, policymakers and the general public since the last decade. The representatives of indigenous peoples have been pushing to engage with climate change agreements since the adoption of the Kyoto Protocol in 1997 [27]. This study, which aims to capture Ivorian local fishermen's perceptions and personal experience of climate change, represents an important contribution to the global effort of combating and reducing climate change. Fishermen are directly dependent on the aquatic ecosystems for their livelihoods. Thus, understanding their perception and knowledge of climate change is an essential step towards developing and implementing adaptation and mitigation strategies to deal with the effects of climate change on aquatic ecosystems.

The high proportion of awareness of climate change obtained is consistent with a study by [28] who argued that the majority of Africa's citizens are aware of change in climate patterns. Many other studies conducted in several parts of Africa found similar results with households [29], farmers [24] and fishers [30, 31]. Since the twentieth century, increases in temperature and decreases in precipitation have been experienced in Cote d'Ivoire [20,32]. In our study, fishermen mainly observed an increase in temperature, a decrease in precipitation and an increase in flood occurrence. Ivorian 


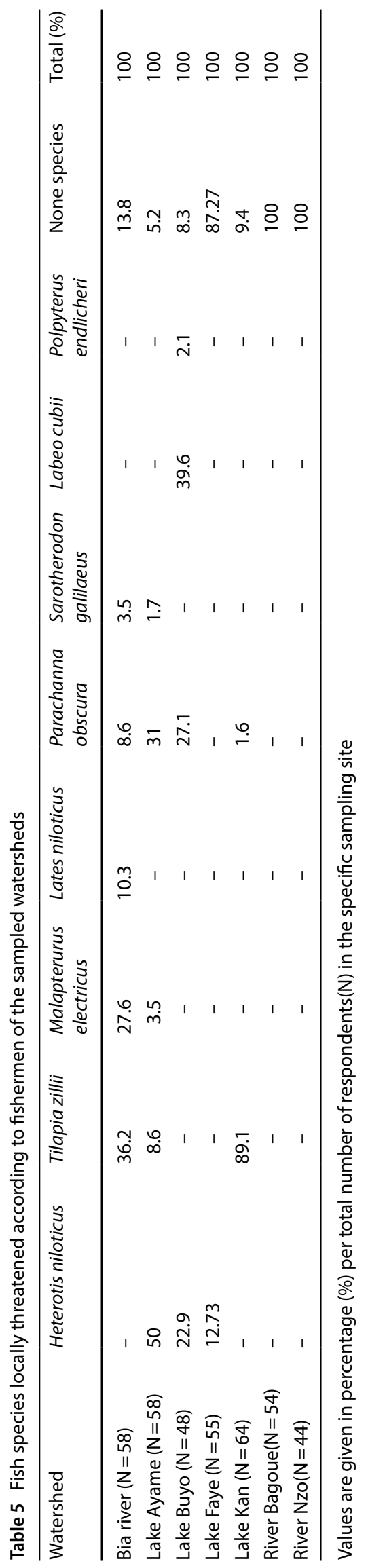


Table 6 Results of multinomial logistic regression of sociodemographic factors determining Ivorian fishermen's awareness of climate change

\begin{tabular}{ll}
\hline Explanatory variable & $\begin{array}{l}\text { Awareness of } \\
\text { climate change } \\
\text { Coef }^{\text {sig }} \text { (St. Err) }\end{array}$ \\
\hline Climatic zone & $-\mathbf{0 . 7 3 0 *}(0.287)$ \\
Fishing watershed & $-0.012(0.101)$ \\
Age & $0.119(0.146)$ \\
Ethnic group & $-0.068(0.051)$ \\
Gender & $0.016(0.445)$ \\
Household size & $\mathbf{0 . 4 1 1 ^ { * } ( 0 . 1 8 9 )}$ \\
Education level & $\mathbf{0 . 5 8 0 * *}(0.104)$ \\
Main occupation & $0.036(0.276)$ \\
Residual Deviance & $\mathbf{3 6 1 . 1 1}$ \\
AIC & $\mathbf{3 7 9 . 1 1}$ \\
\hline
\end{tabular}

Significant correlations in bold, with level of significance indicated by stars, and standard errors in brackets * $a<0.05$; ** $a<0.01$

Table 7 Results of multinomial logistic regression of socio-demographic factors determining Ivorian fishermen's perception of change in climate

\begin{tabular}{|c|c|c|c|c|c|c|}
\hline \multirow[t]{3}{*}{ Explanatory variable } & \multicolumn{2}{|c|}{ Perceived Change in rainfall } & \multicolumn{2}{|c|}{ Perceived Change in temperature } & \multicolumn{2}{|c|}{ Perceived Change in flooding } \\
\hline & Increase & Decreased & Increase & Decreased & Increase & Decreased \\
\hline & $\operatorname{Coef}^{\mathrm{Sig}}$ (St. Err) & $\operatorname{Coef}^{\text {Sig }}$ (St. Err) & $\operatorname{Coef}^{\mathrm{Sig}}$ (St. Err) & Coef $^{\text {Sig }}$ (St. Err) & Coef $^{\text {Sig }}$ (St. Err) & Coef $^{\text {Sig (St. Err) }}$ \\
\hline Climatic zone & $-3.117(2.384)$ & $-0.907(2.307)$ & $0.478(0.401)$ & $0.671(0.628)$ & $-1.445^{* *}(0.302)$ & $0.519(0.819)$ \\
\hline Fishing watershed & $-0.539(0.514)$ & $-0.733(0.486)$ & $0.214(0.175)$ & $-0.641^{* *}(0.248)$ & $\mathbf{0 . 6 7 0 * *}(0.106)$ & $-0.370(0.328)$ \\
\hline Age & $-1.235(0.690)$ & $-1.527^{*}(0.663)$ & $0.458(0.238)$ & $-0.069(0.309)$ & $-0.230(0.141)$ & $-0.245(0.337)$ \\
\hline Ethnic group & $0.543(0.398)$ & $0.616(0.392)$ & $-\mathbf{0 . 2 8 0 * *}(0.069)$ & $-\mathbf{0 . 1 9 7 *}(0.089)$ & $-\mathbf{0 . 3 0 2 * *}(0.049)$ & $-0.039(0.120)$ \\
\hline Gender & $12.139 * *(0.412)$ & $14.398^{* *}(0.412)$ & $1.884(1.342)$ & $\mathbf{3 . 3 6 6 * *}(1.388)$ & $0.271(0.416)$ & $1.115(1.182)$ \\
\hline Household size & $-\mathbf{2 . 1 9 5 * *}(0.821)$ & $-1.773 * *(0.762)$ & $0.140(0.330)$ & $0.496(0.397)$ & $0.261(0.188)$ & $\mathbf{0 . 6 9 5 *}(0.344)$ \\
\hline Education level & $-1.814^{*}(0.728)$ & $-1.530 *(0.717)$ & $-0.016(0.127)$ & $-0.053(0.161)$ & $-0.058(0.089)$ & $0.141(0.198)$ \\
\hline Main occupation & $-0.066(0.794)$ & $-0.870(0.764)$ & $-0.319(0.460)$ & $-0.007(0.463)$ & $0.305(0.204)$ & $\begin{array}{l}-12.793^{* *} \\
(0.00002)\end{array}$ \\
\hline Residual Deviance & 236.66 & & 421.86 & & 483.83 & \\
\hline AIC & 272.66 & & 475.86 & & 519.83 & \\
\hline
\end{tabular}

Significant correlations in bold, with level of significance indicated by stars, and standard errors in brackets ${ }^{*} a<0.05 ;{ }^{* *} a<0.01$

fishermen are therefore well informed of the climate trend. Being aware of local perception and knowledge of climate change is essential for formulating climate change education, communication interventions, and for effectively implementing risk reduction strategies [25]. Our result, which suggests that most of the Ivorian fishermen are well informed of climate change, is a positive feature for global actions against climate change in Cote d'Ivoire. Local fishermen should be associated with the process of decision-making concerning climate change adaptation and mitigation strategies.

According to previous studies, the demographic background of individuals represents an important factor that influences their awareness and perception of climate change [24, 29, 33, 25]. For instance, [25] have shown that sociodemographic factors such as gender, age and education have a great influence on farmers' knowledge and perception of climate change. The result of the multinomial logit regression model, which highlighted the significant importance of demographic variables such as age, gender, household size ethnic group and education level in fishermen awareness and perception of climate change, corroborates these findings. Interviewees' awareness of "climate change" was positively influenced by educational level. Our finding is consistent with those of [29] and [34] which showed an increase of respondents' knowledge of climate with education level. Thus, people with higher educational levels are more likely to get access to information related to climate change than those with low educational levels. The same observations were 
Table 8 Results of multinomial logistic regression of sociodemographic factors influencing Ivorian fishermen's perception of change in fish abundance

\begin{tabular}{|c|c|c|c|}
\hline \multirow[t]{3}{*}{ Explanatory variable } & \multicolumn{3}{|c|}{ Perceived Change in fish abundance } \\
\hline & Low decrease & Moderate decrease & Significant decrease \\
\hline & Coef $^{\text {Sig }}$ (St. Err) & Coef $^{\text {Sig }}$ (St. Err) & Coef $^{\text {Sig }}$ (St. Err) \\
\hline Climatic zone & $0.156(1.041)$ & $0.378(1.160)$ & $\mathbf{2 . 3 6 4 *}(0.965)$ \\
\hline Fishing watershed & $-0.294(0.301)$ & $-0.851(0.483)$ & $-1.009^{* *}(0.274)$ \\
\hline Age & $1.604^{* *}(0.556)$ & $1.909 * *(0.646)$ & $1.607^{* *}(0.532)$ \\
\hline Ethnic group & $0.219(0.164)$ & $\mathbf{0 . 8 5 8}^{* *}(0.227)$ & $0.123(0.156)$ \\
\hline Gender & $1.633(2.231)$ & $0.249(3.157)$ & $-1.205(2.175)$ \\
\hline Household size & $-0.430(0.539)$ & $-1.123(0.855)$ & $0.100(0.479)$ \\
\hline Education level & $0.365(0.240)$ & $0.083(0.347)$ & $0.491 *(0.220)$ \\
\hline Main occupation & $-3.218(2.427)$ & $0.222(2.906)$ & $1.708(2.165)$ \\
\hline Residual Deviance & 334.245 & & \\
\hline AIC & 388.245 & & \\
\hline
\end{tabular}

Significant correlations in bold, with level of significance indicated by stars, and standard errors in brackets ${ }^{*} a<0.05 ;{ }^{* *} a<0.01$

done by [35], where higher levels of knowledge of individuals allowed them to better assess the threats posed by climate change and reduced the perceived level of uncertainty related to climate change and the impact of pro-environmental behaviours.

Freshwater fishes represent an important and vital component of the food of many people in sub-Saharan Africa [11]. Our study suggests that most of the respondents observed significant declines in fish quantity. Climate change, especially change in temperature and rainfall were acknowledged to contribute to this decline in Ivorian freshwater fish abundance. Additionally, many anthropogenic activities including gold mining, water withdrawal for human needs, use of small-mesh fishing nets, overfishing, industrial waste discharge, pesticides use for agricultural purposes along watersheds, obnoxious fishing practices and increase in human population, were listed by fishermen as other stressors contributing in depletion of Ivorian freshwater fish abundance. Since the independence of Côte d'Ivoire, a set of laws and regulations has been adopted for the sustainable management of the fisheries sector [36]. The most recent is the law $n^{\circ} 2016-554$ of 26 July 2016 on fisheries and aquaculture, which provides dispositions relating to the regulation and sustainability of aquatic resources, in particular in its articles 8,9,10,11 and 12 [37]. The dispositions in these articles define the set of measures such as the types of fishing engines allowed, the size of fishing nets allowed, the prohibition of fishing on protected species, the prohibition of the use of any explosive materials, toxic substances or baits likely to weaken, stun, excite or kill aquatic resources or to infect their habitats, etc. However, based on information provided by fishermen, there is clear evidence of a lack of application of these measures by fishermen communities. Thus, awareness-raising campaigns on the important values of freshwater ecosystem biodiversity, especially those of fish species, for human livelihoods, and the necessity to preserve these ecosystems for the benefit of future generations are necessary. Similarly, populations living in areas surrounding freshwater habitats should be informed on practices that negatively impact the biodiversity of freshwater ecosystems. In addition, further measures such as a prohibition on fishing during reproduction seasons of fish species, introduction of laws imposing prison sentences to those engaged in obnoxious fishing practices, establishment of buffer zones between watersheds and agriculture farms in order to prevent pesticides used in agriculture to get water bodies, enforcement of mining and agricultural industries to treat their waste before discharging it into waterways, should be taken by the Ivorian government in agreement with local fishery management authorities. These additional measures will contribute to strengthening the existing aquatic resources management policy, then allow the sustainable use of these resources. To reduce the effect of climate change on fish abundance, greenhouse gas emissions and deforestation must be reduced, and reforestation campaigns should be increased all over the country. Another solution for the mitigation of climate change is the protection of watershed forests.

The listed factors threatening Ivorian freshwater fish biodiversity in our study are among the wide spectra of factors threatening Africans' freshwater ecosystems in general. Indeed, according to [11], climate change, water pollution, habitat loss due to deforestation, overfishing, mining, and agriculture represent the greatest threats to freshwater fishes in Africa and specifically in West Africa [11]. For instance, impact of climate change was observed in Lake Chad located in West Africa between 1960s and 2001, where the surface area of water was reduced to $5.4 \%$ of its initial level (50\% caused 
by climate change), leading to the loss of many aquatic organisms taxa [9, 38]. Also, according to [39], natural disasters (e.g., droughts) represent the second most serious cause of decline for around $70 \%$ of the freshwater fishes in northern Africa. In Kinshasa and Lagos, pollution from oil exploration, cars in the cities, factories or other urban industries, and from boat traffic are impacting freshwater ecosystems. Pollution from oil exploration, combined with habitat loss, specifically threatens many restricted-range species in the Niger Delta and may pose a threat to species in coastal freshwater of the Republic of Congo, Cabinda, Gabon and Angola [9]. Congo freshwater ecosystem was additionally reported to suffer from mercury discharge linked to gold mining activities. In Lower Guinea, freshwater species are particularly threatened by intensive land use and pollution from rubber, banana, and palm oil plantations [9]. Another example is the case of eastern slopes of Mount Cameroon, where freshwater fish biodiversity is impacted by habitat loss due to agriculture. In Benin and the Volta region of Africa, overfishing was reported to cause changes in fish community structures and distributions $[40,11]$.

Research studies examining the survival of extremely rare, cryptic or possibly extinct species often rely on local knowledge rather than on direct study of these species. While there is considerable potential for error and bias in the collection and interpretation of traditional ecological knowledge from local informants [41], this research approach provides a unique source of data with substantial applicability for conservation $[42,43]$. Fish species populations declines have been supported by fisher's perceptions in several studies that have assessed freshwater fish species [42] and the marine one as well [44-46]. The study by [44] in the Eastern Brazilian Marine Park corroborated the decline of seven of the reef fish species by fishers. These declines were mostly due to heavy fishing pressure and overfishing along the Brazilian coast [44]. Another example is the study by [42], which demonstrated the strong awareness of fishers of the major declines in many fish species in the Yangtze River in recent decades. In our study, the species reported by respondents as locally scarce or under threat or with their populations in depletion are all classified in the category of least concern in the IUCN red list. Heterotis niloticus is a pelagic species that frequent shallow waters of rivers and lakes for the adults, and marshy places among aquatic vegetation for the young [47]. Tilapia zillii, Parachanna obscura and Lates niloticus are demersal and potamodromous species. Tilapia zillii is caught in shallow marginal waters, drowned forest areas and also on sandy shores [48]. Lates niloticus inhabits channels, lakes and irrigation canals, prefers sandy bottoms, but is also found in rocky to muddy bottoms. Vegetated areas in calm waters provide shelter for its larvae and young [49]. Parachanna obscura is a deep-water inhabitant and migratory freshwater species found mainly in floodplains, swamps, rivers, lakes, ponds and streams [50]. This species breeds throughout the year, but preferably during and just after floods. Sarotherodon galilaeus is also demersal and occurs in the shallow coastal waters of lakes and prefers open water, but juveniles and breeding adults can be found offshore [51]. In lakes, it is often associated with beds of submerged vegetation. Malapterurus electricus inhabits shallow waters with muddy or sandy bottoms, close to rocky areas, and prefers stagnant or slow-moving water [52]. Labeo coubie is a benthopelagic and potamodromous species living in rivers and lakes, and mainly sheltered bays [53]. All of these species breed on seasonal floodplains, overflooded areas or in marginal vegetated areas of the catchment. Thus, any change in the rainy season pattern (late or early arrival, shortening, etc.) or any reduction in rainfall can disrupt their reproduction and spawning. Also, given that fish are often adapted to a certain level of hydrological variability, changes in this variability could have negative effects on fish populations [54]. Unusually large floods or seasonal pulses can displace adults and displace or injure juveniles and larvae, and droughts or prolonged dry spells can lead to population declines as well as reductions in abundance and changes in species composition [55, 54]. According to the fishermen, there has been a decrease in rainfall and a change in the onset and length of the rainy season as well as an increase in floods occurrence. Thus, this can probably explain why these species were reported as locally threatened by respondents. Freshwater fish are all exotherms, unable to regulate their body temperature by physiological means and having a body temperature virtually identical to that of their environment [54]. Consequently, increasing global temperatures can affect them by altering physiological functions such as thermal tolerance, growth, metabolism, food consumption, reproductive success and the capacity to maintain internal homeostasis in the face of a variable external environment [56]. Fish populations that experience changing thermal regimes may increase or decrease in abundance, experience range expansions or contractions, or be threatened with extinction [54]. The increase in temperature observed by fishermen can illustrate the decline of the population of these species. In addition, due to the preference of these species for vegetation or forest areas, agriculture expansion and pesticide use along watersheds may pose a threat to their habitat and populations. Agriculture and pesticide use along watersheds were listed by the fishermen in this study among anthropogenic activities threatening the Ivorian freshwater ecosystem. Most of the species listed are among the main species of the Ivorian fishery [57]. Overfishing has been reported by fishermen as one of the threats to the biodiversity of Ivorian freshwater fish. Thus, it may represent one of the probable causes of the rarity of these species. According to the result of a recent study on the assessment of the conservation status and the vulnerability of the ichthyofauna 
of the Bandama River in Côte d'Ivoire, species such as Lates niloticus, Labeo coubie, Heterotis niloticus and Sarotherodon galilaeus, despite their status as species of least concern, were assessed as vulnerable to fishing pressure [17]. Many other studies carried out on the African continent have reported that these species are locally threatened by many humans' actions and climate change. Lates niloticus is reported to suffer from over-exploitation in much of its native range, and to a lesser extent, pollution [58]. Heterotis niloticus and Parachanna obscura are also affected by overfishing in central and western Africa respectively, where they represent commercially important fish species [47, 59]. Malapterurus electricus, Sarotherodon galilaeus, Tilapia zillii and Labeo coubie are threatened by dam constructions, water pollution, groundwater extraction and drought in northern Africa, whereas Malapterurus electricus and Sarotherodon galilaeus are additionally affected by overfishing in eastern Africa [51, 53, 52, 48].

\section{Conclusion and perspectives}

Côte d'Ivoire is a climatically diverse country with a great diversity of freshwater ecosystems.

The results of this study show good awareness among local fishermen of climate change and its drivers. That climatic awareness represents a positive prerequisite for the implementation of measures toward climate mitigation and population adaptation. Fish abundance reduction was reported as a consequence of climate change and several anthropogenic activities. In response to this reduction in fish quantity, the government must ensure the strict application of policies and regulations in force in the fisheries sector, through the establishment of local management and monitoring committees. These should be done by involving fishermen associations (or cooperatives) in the process of decision making, their implementation, and monitoring. This will improve the effectiveness of actions and contribute to the sustainable management of fishing resources. In addition, to enable fishing communities to adapt to the decline of fish, they need to be trained to diversify their sources of income. For example, training them in agriculture (livestock, aquaculture, etc.) or other activities such as mechanics, commerce, electricity, etc. This will not only strengthen their adaptive capacities but also reduce excessive pressures on aquatic ecosystems. All these measures should be implemented through fishermen associations or cooperatives. In Côte d'Ivoire, fishermen are mainly organized in cooperatives or associations [60]. The roles of these are most often to contribute to food security, poverty eradication, promotion of collective action, empowerment of fishermen to respond to environmental and socio-economic changes, and sharing of responsibility in the practice of responsible fishing, but also to have a good voice in the social-economic process. However, the movement of cooperatives or associations in the fisheries sector is characterised by a lack of dynamism in Côte d'Ivoire. Those function with difficulty, thus giving the impression that there are no existing fisheries actors in Côte d'Ivoire[60]. Thus, the government should first revitalise the associations or cooperatives by providing financial supports, but also train them on their roles and duties.

The information provided by fishermen constitutes basic information on the evolutions and the main factors impacting fish abundance in Ivory Coast. These are useful for directing and approving adaptation and management strategies of fish resources. These results should be supported by further studies that will focus on quantifying the level of decrease in fish quantity, the contribution of each threat in this decline, the level of correlation between these threats, the identification of the most impactful threats, and the assessment of the vulnerability and the already existing local adaptation strategies in Ivorian local fishermen communities. These will give a clear view on which management strategies will be more appropriate for the sustainability of fish resources and how to improve the existing adaptation strategies.

Fish species listed by fishermen as being threatened are economically among the most important fish species for the livelihood of many African countries, especially in Côte d'Ivoire. The reassessment of the local status of these species using IUCN criteria is needed to guide management and conservation policies. Furthermore, more research studies are needed to assess and quantify the vulnerability of these species to climate change and human activities. The assessment of the distribution, genetic diversity and population dynamics of these species will also be necessary to develop appropriate management and conservation policies.

Acknowledgements We are grateful to Côte d'Ivoire ministry of water and animal resources local officers from the sampling localities for providing all the support needed during fieldwork. Our thanks go to local fishermen associations for their support.

Authors' contributions AAl participated in the collection and analysis of the data, as well as the writing of the manuscript. ONB and AK participated in the writing of the manuscript and in the data analysis. TM and KEP guided and supervised the project, reviewed and approved the final manuscript. 
Funding This study was supported by the West African service centre of Climate Change and Adapted Land-use scholarship programme funded by German Federal Ministry for Education and Research.

Data availability The datasets generated during and/or analysed during the current study are available from the corresponding author on reasonable request.

Code availability The datasets generated during and/or analysed during the current study are available from the corresponding author on reasonable request.

Declarations

Ethics approval and consent to participate Not applicable.

Consent for publication Not applicable.

Competing interests The authors declare no competing interests.

Open Access This article is licensed under a Creative Commons Attribution 4.0 International License, which permits use, sharing, adaptation, distribution and reproduction in any medium or format, as long as you give appropriate credit to the original author(s) and the source, provide a link to the Creative Commons licence, and indicate if changes were made. The images or other third party material in this article are included in the article's Creative Commons licence, unless indicated otherwise in a credit line to the material. If material is not included in the article's Creative Commons licence and your intended use is not permitted by statutory regulation or exceeds the permitted use, you will need to obtain permission directly from the copyright holder. To view a copy of this licence, visit http://creativecommons.org/licenses/by/4.0/.

\section{Appendix 1: Survey questionnaire on "Fishermen's perceptions and experiences toward the impact of climate change and anthropogenic activities on freshwater fish biodiversity in Côte d'Ivoire".}

Questionnaire number:

\section{Socio-demographic information}

1. Locality

2. Watershed

3. Climate zone

4. Ethnic group

5. Gender 1) Male [...] 2) Female [...]

6. Age: 1) $20-29[\ldots]$; 2) 30-39 [...] ; 3) 40-49 [...]; 4) 50-59 [...]; 5) 60 and over [...]

7. Marital status: 1) Married [...]; 2) Single [...]; 3) Widowed [..]; 4) Divorced [...]; 5) No answer [...]

8. Household size 1) 1-5 [...] 2) 6-10 [..]; 3) 11-15 [...]; 4) 16-20 [..]; 5) 21-25 [...] 6) 26 and over[...]

9. Education level; 1) Illiterate [...] 2) Primary [...]; 3) Junior high school [...]; 4) Senior high school [...]; 5) University [...]

10. Main occupation

11. Secondary occupation

12. Monthly income

\section{Perception of climate change and its drivers}

1. Are you aware of "climate change"? 1) yes [...];2) no [...]

2. What do you think is the major cause or driver of climate change?1) greenhouse gas emissions [...]; 2) Land-use change [...]; 3) Deforestation;4) Volcanoes;5); Solar radiation [...]; 6) Other

3. Have you observed any change in the rainfall over the past years? 1) No change [...];2) Increase [...]; 3) Decrease [...]; 4) I don't know [...]

4. Have you observed any change in the timing of the rainy seasons over the past years? 1) No change [...];2) early arrival $[. .] ;$.3 ) late arrival $[\ldots]$; 4) I don't know [...] 
5. Have you observed any change in the length of the rainy seasons over the past years? 1) No change [...];2) 2) lengthening [...]; 3) Shortening [...]; 4) I don't know [...]

6. Have you observed any change in the temperature over the past years? 1) No change [...];2) Increase [...];3) Decrease [...]; 4) I don't know [...]

7. Have you observed any change in flooding occurrence over the past years? 1) No change [...]; 2) Increase [...]; 3) Decrease [...]; 4) I don't know [...]

\section{Perception of the impact of climate change and human activities on fish biodiversity.}

1. Have you observed any decrease in fish abundance or quantity in your fishing watersheds over the past years? 1) No decrease $[\ldots]$; 2) low decrease $[\ldots]$; 3) moderate decrease $[\ldots]$; 4) significant decrease [...]; I don't know [...]

2. How have temperature changes affected fish abundance or quantity? 1) No effect [...] 2) Increase [...]; 3) Decrease [...]; 4) I don't know [...]

3. How have rainfall changes affected fish abundance or quantity? 1) No effect [...] 2) Increase [...]; 3) Decrease [...]; 4) I don't know [...]

4. For you, what are the human actions or activities that affect/impact negatively fish biodiversity in your fishing watersheds?

5. Have you noticed the scarcity or the depletion of populations or the disappearance of particular species of fish in your fishing watersheds? 1) Yes [...]; 2) No [...]

6. If yes, can you please provide the name(s) of this or these species?

\section{Any other comments?}

\section{References}

1. UNFCCC. United nations framework convention on climate change. 1992. https://unfccc.int/resource/docs/convkp/conveng.pdf. Accessed 10 Jan 2021.

2. Bassem SM. Water pollution and aquatic biodiversity. Biodivers Int J. 2020;4(1):10-6. https://doi.org/10.15406/bij.2020.04.00159.

3. Liermann CR, Nilsson C, Robertson J, Ng RY. Implications of dam obstruction for global freshwater fish diversity. Bioscience. 2012;62(6):53948. https://doi.org/10.1525/bio.2012.62.6.5.

4. Costello MJ. Biodiversity: the known, unknown, and rates of extinction. Curr Biol. 2015;25:R368-71. https://doi.org/10.1016/jcub201503 051.

5. Robert R, Amit NH, Sukarno NM, Majapun RJ, Kumar SV. Population genetic structure of Asian snakehead fish (Channa striata) in North Borneo: Implications for conservation of local freshwater biodiversity. Ecol Res. 2019;34(1):55-67. https://doi.org/10.1111/1440-1703. 1008.

6. UNESCO. The united nations world water development report: water for people, water for life. Paris: UNESCO \& Berghahn Books; 2003.

7. Vörösmarty CJ, Green P, Salisbury J, Lammers RB. Global Water resources: vulnerability from climate change and population growth. Science. 2000;289(5477):284-8. https://doi.org/10.1126/science.289.5477.284.

8. Xenopoulos MA, Lodge DM, Alcamo J, Marker M, Schulze K, Van Vuuren DP. Scenarios of freshwater fish extinctions from climate change and water withdrawal. Glob Change Biol. 2005;11(10):1557-64. https://doi.org/10.1111/j.1365-2486.2005.001008.x.

9. Darwall WRT, Smith KG, Allen DJ, Holland RA, Harrison IJ, Brooks EGE (eds). The Diversity of Life in African Freshwaters: Under Water, Under Threat. An analysis of the status and distribution of freshwater species throughout mainland Africa. Cambridge, United Kingdom and Gland, Switzerland: IUCN; 2011.

10. Lévêque C, Oberdorff T, Paugy D, Stiassny MLJ, Tedesco PA. Global diversity of fish (Pisces) in freshwater. Hydrobiologia. 2008;595:545-67. https://doi.org/10.1007/978-1-4020-8259-7_53.

11. Smith K G, Diop MD, Niane M, Darwall WRT (Compilers). The status and distribution of freshwater biodiversity in Western Africa. Gland, Switzerland and Cambridge, UK: IUCN x+94pp+4pp cover; 2009.

12. Brummett R, Tanania C, Pandi A, Ladel J, Munzimi Y, Russell A, Stiassny M, Thieme M, White S, Davies D. Water resources, forests and ecosystem goods and services. In: De Wasseige C, DeversMarcken DP, Eba'a AtyiMayaux RP, editors. The forests of the Congo Basin: state of the forest 2008. Luxembourg: Publications Office of the European Union; 2009. p. 1411-2157. 
13. Brooks EGE, Allen DJ, Darwall WRT (compilers). The Status and distribution of freshwater biodiversity in Central Africa. Gland, Switzerland and Cambridge, UK: IUCN; 2011. x+126pp.

14. Darwall WRT, Smith KG, Lowe T, Vié, JC. The status and distribution of freshwater biodiversity in Eastern Africa IUCN. Gland, Switzerland and Cambridge, UK; 2005.

15. World Bank. Understanding Côte d'Ivoire's sustainable development issues in five charts 1-6.World bank Publishing website. 2018.https:// www.worldbank.org/en/country/cotedivoire/publication/cote-d-ivoire-economic-update-understanding-cote-d-ivoire-sustainable-devel opment-issues-in-five-charts. Accessed 20 Feb 2021

16. USAID (United States Agency for International Development). Property rights and resource governance: Côte d'Ivoire 40. 2017. https:// www.land-links.org/wp-content/uploads/2016/09/USAID_Land_Tenure_Cote_dlvoire_Profile.pdf. Accessed 20 Jan 2021.

17. Ouattara D, Assi SR, Konan KS, Boussou KC. Assessment the conservation status and vulnerability of the ichthyological population of the Bandama River in the Marahoué Region (Central West of Côte d'Ivoire). Int J Biodivers Conserv. 2021;13(3):120-6. https://doi.org/10. 5897/IJBC2021.1484.

18. Groga N, Ouattara A, Costa SD, Dauta A, Beauchard A, Beauchard O, Gourene JMG, Laffaille P. Water quality and water-use conflicts in Lake Taabo (Ivory Coast). Open J Ecol SCIRP. 2012;2:38-47.

19. Gueu A, Ouffoué S, Digbéhi B. Mercury Concentration profile in sediment cores of a tropical lagoon under high anthropogenic activities around an Urban City_Abidjan, Côte d'Ivoire. J Geosci Environ Prot. 2021;9:83-94. https://doi.org/10.4236/gep.2021.95007.

20. Bernard DK. Document de stratégie du programme national changement climatique (2015-2020). Ministère de l'environnement, de la salubrité urbaine et du développement durable, République de Côte d'Ivoire. 2014. http://www.environnement.gouv.ci/pollutec/CTS3\% 20LD/CTS\%203.4.pdf. Accessed 10 July 2021.

21. Bruchac M. Indigenous knowledge and traditional knowledge. In: Smith C, editor. Encyclopedia of global archaeology. New York: Springer; 2014. p. 3814-24.

22. Vidal J. Why indigenous knowledge peoples and traditional knowledge are vital to protecting future global biodiversity. 2019. https:// ensia.com/features/indigenous-knowledge-biodiversity/. Accessed 20 Jul 2021.

23. Dagnelie $P(1998)$ Statistiques théoriques et appliquées. Bruxelles, Belgique: de Boeck et Larcier.

24. Agwu OP, Bakayoko A, Jimoh SO, Stefan P. Farmers' perceptions on cultivation and the impacts of climate change on goods and services provided by Garcinia kola in Nigeria. Ecol ProcesS. 2018. https://doi.org/10.1186/s13717-018-0147-3.

25. Owusu M, Nursey-bray M, Rudd D. Gendered perception and vulnerability to climate change in urban slum communities in Accra, Ghana. Reg Environ Change. 2019;19:13-25. https://doi.org/10.1007/s10113-018-1357-z.

26. Starkweather J, Moske KA. Multinomial logistic regression. 2011. file:///D:/DDA/mlr_jds_aug2011.pdf. Accessed 20 Jul 2021.

27. Etchart L. The role of indigenous peoples in combating climate change. Palgrave Commun. 2017;3:17085. https://doi.org/10.1057/palco mms.2017.85.

28. Taderera D. South African's awareness of climate change. Briefing Paper 235 Southern African Catholic Bishops' Conference, Parliamentary Liaison Office, South Africa; 2010.

29. Amos E, Akpan U, Ogunjobi K. Households' perception and livelihood vulnerability to climate change in a coastal area of Akwa Ibom State, Nigeria. Environ Dev Sustain. 2015;17(4):887-908. https://doi.org/10.1007/s10668-014-9580-3.

30. Bah OA, Kone T, Yaffa S, Sawaneh M, Kone D. Fishers' perceptions of climate change on freshwater fisheries and the role of these systems in their adaptation strategy in central river Region of the Gambia. IJAER. 2018;02:321-40.

31. Utete B, Phiri C, Mlambo SS, Muboko N, Fregene BT. Vulnerability of fisherfolks and their perceptions towards climate change and its impacts on their livelihoods in a peri-urban lake system in Zimbabwe. Environ Dev Sustain. 2019;21(2):917-34. https://doi.org/10.1007/ s10668-017-0067-x.

32. Soro GÉ, Dao A, Fadika V, Bi AG, Srohorou B. Estimation des pluies journalières extrêmes supérieures à un seuil en climat tropical : cas de la Côte d'Ivoire. Physio-Géo. 2016;10(2):11-227. https://doi.org/10.4000/physio-geo5011Abstracts.

33. Combest-Friedman C, Christie P, Miles E. Household perceptions of coastal hazards and climate change in central Phillippines. J Environ Manage. 2012;112:137-48. https://doi.org/10.1016/jjenvman201206018.

34. Nzeadibe TC, Egbule CL, Chukwuone NA, Agwu AE, Agu VC. Indigenous innovations for climate change adaptation in the Niger Delta region of Nigeria Environment. Dev Sustain. 2012;14:901-14. https://doi.org/10.1007/s10668-012-9359-3.

35. Yu TK, Lavallee JP, Di Giusto B, et al. Risk perception and response toward climate change for higher education students in Taiwan. Environ Sci Pollut Res. 2020;27:24749-59. https://doi.org/10.1007/s11356-019-07450-7.

36. FAO. Vue génerale du secteur des pêches national la république de côte d'ivoire. 2008. https://www.fao.org/fishery/docs/DOCUMENT/ $\mathrm{fcp} / \mathrm{fr} / \mathrm{FI}$ CP_Cl.pdf. Accessed 12 Nov 2021.

37. Assemblée nationale, république de Côte d'Ivoire. Loi n $2016 \cdot 554$ du 26 juillet 2016 relative à la pêche et à l'aquaculture. 2016. http:// extwprlegs1.fao.org/docs/pdf/ivc159952.pdf. Accessed 12 Nov 2021.

38. Peitersen K, Beekman H. Freshwater. In: Mohamed-Katerere J C, Sabet M (eds), Environment outlook 2 section 2 environmental stateand-trends: 20-year retrospective UNEP. 2006.

39. García N, Cuttelod A, Abdul Malak D (eds). The status and distribution of freshwater biodiversity in Northern Africa. IUCN, Gland, Switzerland, Cambridge, UK, and Malaga xiii+141pp.

40. Helfman GS. Fish conservation: a guide to understanding and restoring global aquatic biodiversity and fishery resources. Washington $D$ C: Island Press; 2007.

41. McKelvey KS, Aubry KB, Schwartz MK. Using anecdotal occurrence data for rare or elusive species: the illusion of reality anda call for evidentiary standards. Bioscience. 2008;58:549-55.

42. Turvey ST, Barret LA, Yujiang H, Lei Z, Xinqiao Z, Xinyan W, et al. Rapidly shifting baselines in Yangtze fishing communities and local memory of extinct species. Conserv Biol. 2010;3:778-87.

43. Drew JA. Use of traditional ecological knowledge in marineconservation. Conserv Biol. 2005;19:1286-93.

44. Bender MG, Floeter SR, Hanazaki N. Do traditional fishers recognise reeffish species declines? Shifting environmental baselines in Eastern Brazil. Fish Manage Ecol. 2013;20:58-67. https://doi.org/10.1111/fme.12006. 
45. Lavides MN, Polunin NVC, Stead SM, Tabaranza DG, Comeros MT, Dongallo JR. Finfish disappearances around Bohol, Philippines inferred from traditional ecological knowledge. Environ Conserv. 2010;36:235-44.

46. O'Donnell KP, Pajaro MG, Vincent CJ. How does the accuracy of fisher knowledge affect seahorse conservation status? Anim Conserv. 2010;13:526-33.

47. Diouf K, Akinyi, E, Azeroual A, Entsua-Mensah M, Getahun, A, Lalèyè P, Moelants T. Heterotis niloticus. The IUCN Red list of threatened species: e T182580A134764025. 2020a. https://doi.org/10.2305/IUCNUK.20202.RLTS.T182580A134764025.en

48. Lalèyè P. Coptodon zillii. The IUCN Red List of Threatened Species: eT183163A64508317. 2020b. https://doi.org/10.2305/IUCN.UK.20202. RLTS.T183163A64508317.en

49. Froese, R. and Pauly, D. (eds). FishBase. World Wide Web electronic publication; 2003.

50. Teugels GG. Channidae. p. 443-446 In C. Lévêque, D. Paugy and G.G. Teugels (eds.) Faune des poissons d'eaux douce et saumâtres de I'Afrique de I'Ouest, Tome 2. Coll. Faune et Flore tropicales 40. Musée Royal de l'Afrique Centrale, Tervuren, Belgique, Museum National d'Histoire Naturalle, Paris, France and Institut de Recherche pour le Développement, Paris, France; 2003.815 p.

51. Diallo I, Awaïss A, Azeroual A, Bousso T, Getahun A, Hanssens M, Lalèyè, P, Moelants T, Odhiambo E. Sarotherodon galilaeus. The IUCN red list of threatened species: e T62220A58310155. 2020a; https://doi.org/10.2305/IUCN.UK.20203.RLTS.T62220A58310155.en .

52. Diouf K, Azeroual A, Entsua-Mensah M, Getahun A, Lalèyè P, Kazembe J.Malapterurus electricus. The IUCN Red list of threatened species: e T182850A135694315. 2020b. https://doi.org/10.2305/IUCN.UK.2020-2.RLTS.T182850A135694315.en

53. Diallo I, Azeroual A, Entsua-Mensah M, Getahun A, Hanssens M, Lalèyè P, Moelants T, Twongo TK. Labeo coubie. The IUCN red list of threatened species: e T182352A134942755. 2020b; https://doi.org/10.2305/IUCN.UK.2020-3.RLTS.T182352A134942755.en

54. Ficke AD, Myrick CA, Hansen LJ. Potential impacts of global climate change on freshwater fisheries. Rev Fish Biol Fisheries. 2007;17:581-613. https://doi.org/10.1007/s11160-007-9059-5.

55. Matthews WJ, Marsh-Matthews E. Effects of drought on fish across axes of space, time and ecological complexity. Freshwater Biol. 2003;48:1232-53.

56. Fry FEJ. The effect of environmental factors on the physiology of fish. In: Hoar WS, Randall DJ, editors. Fish physiology: environmental relations and behavior. New York: Academic Press; 1971. p. 1-98.

57. Kassoum T. Etat des connaissances sur les pecheries continentales ivoiriennes. 1996. http://www.fao.org/3/ag188f/AG188F05.htm. Accessed 15 Jul 2021.

58. Lalèyè $\mathrm{P}$, Azeroual A, Entsua-Mensah M, Getahun A, Moelants T, Ntakimazi G. Lates niloticus. The IUCN Red List of Threatened Species: e T181839A84244538. 2020c. https://doi.org/10.2305/IUCN.UK.2020-2.RLTS.T181839A84244538.en

59. Lalèyè, P. Parachanna obscura The IUCN Red List of Threatened Species: e T183172A134772875. 2020a; https://doi.org/10.2305/IUCN.UK. 20202.RLTS.T183172A134772875.en

60. Zran GM. Organisation des pêcheurs artisans en Côte d'Ivoire : cas de la coopérative Anouanzê d'Adiake. Am J Innov Res Appl Sci. 2020;11(6):200-7.

Publisher's Note Springer Nature remains neutral with regard to jurisdictional claims in published maps and institutional affiliations. 